\title{
A Narrative of Dreams: Chopin's Polonaise-Fantaisie
}

\section{Uma Narrativa de Sonhos: a "Polonaise-Fantasia" de Chopin}

\author{
Michael L. Klein \\ Temple University, USA \\ michael.klein@temple.edu
}

\begin{abstract}
This essay discusses Chopin's Polonaise-Fantaisie from a narrative point of view, arguing that in addition to considering musical narrative as a study of affective logic, it also requires a consideration of cultural ideas at play in the music. The essay ar gues that in the Polonaise-Fantaisie one of the cultural oppositions involves dreaming vs. doing. This polonaise has difficulty maintaining the proper military (doing) aspect common to the genre, often falling into sections that signify dreaming. For example, a nocturne appears in the middle of the work, and various interruptions of the polonaise theme pull it away from its significations of action. The essay discusses the double apotheosis of the polonaise and nocturne themes, arguing that the work is making a statement about how dreaming and acting must come together for action to be meaningful. The essay concludes by detailing how the Polonaise-Fantaisie can prompt us to reconsider modern subjectivity, since the sections about dreaming point to a growing sense of our inner life, which was a growing concern in the nineteenth-century.
\end{abstract}

Keywords: Chopin; narrative; polonaise; nocturne; apotheosis; subjectivity.

Resumo: Este ensaio discute a Polonaise-Fantasia de Chopin de um ponto de vista narrativo, argumentando que, além de considerar a narrativa musical como um estudo de lógica afetiva, ela também requer que se considere as ideias culturais em jogo na música. O ensaio argumenta que na Polonaise-Fantasia uma das oposições culturais envolvidas é o "sonhar" versus o "fazer". Esta polonaise tem dificuldade de manter seu aspecto militar correto ("fazer") comum ao gênero, e frequentemente recai em seções que significam estar sonhando. Por exemplo, um noturno aparece no meio da obra, e várias interrupções da polonaise impulsionam-na para longe das significações de ação. $\mathrm{O}$ ensaio discute a dupla apoteose dos temas da polonaise e do noturno, argumentando que a obra faz uma asserção sobre como "sonhar" e "fazer" devem vir juntos para que a ação tenha sentido. O ensaio termina detalhando como a Polonaise-Fantasia pode nos dispor a reconsiderar a subjetividade moderna, uma vez que as seções sobre "sonhar" apontam para uma crescente consciência da vida interior, uma preocupação marcante no século dezenove.

Palavras-chave: Chopin; narrativa; polonaise; noturno; apoteose; subjetividade.

\section{MUSICA THEORICA}




\section{1 - The End}

I'll begin at the end. Having brought the two main themes of Chopin's Polonaise-Fantaisie to an apotheosis and a satisfactory cadence in the home key at m. 268, the musical persona turns to a quick celebratory dashing up and down the keyboard in double octaves (Example 1).

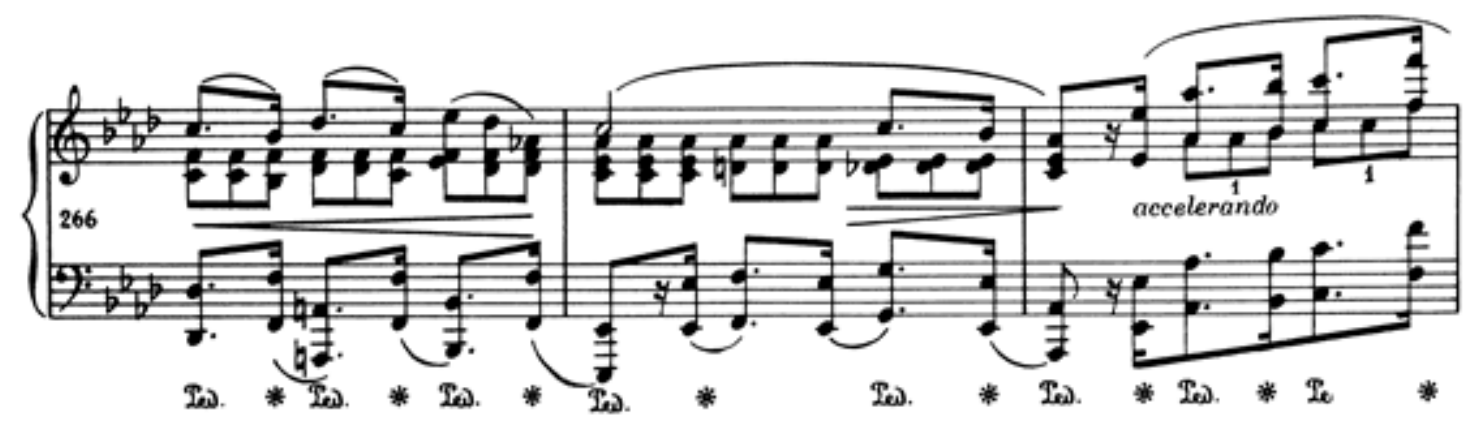

Example 1: Cadence after Apotheosis of Polonaise-Fantaisie

After this virtuosic display, the music dies down, as if settling into the afterglow of success. A shiver of trills in the left hand, and a move to the minor subdominant in the right hand (mm. 281-85) question the reality of the past success, and the piece concludes with three tonic triads (Example 2).

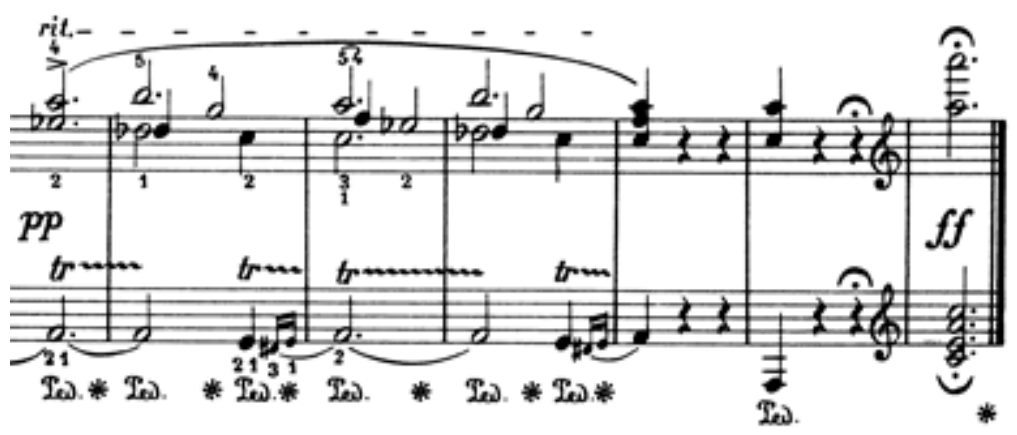

Example 2: Final Measures of Polonaise-Fantaisie

The first two chords are hushed in the lower register, while the final chord is a sudden bell-like jolt in the upper register. What are we to make of this last chord, which is much too high to mark the heroic end of a conventional polonaise? Chopin might have given the higher chord more support in the low register to give the polonaise a properly heroic ending. Or he might have continued the first impulse of the music to fade away into silence, although that does seem counter to the triumph of the final section. Most pianists simply ramp up the final chord with a percussive jab that announces a victorious end to the 
piece. I confess I dislike this solution as an overwrought and obvious ploy to signal the applause sign. Simple as they are, these final chords pose a hermeneutic question that will be the focus of this article. To answer that question, I will turn to a narrative analysis of some portions of the work. Anthony Newcomb has argued that the formal and thematic oddities of the PolonaiseFantaisielend it its narrative aspect, although he refrains from detailing what that narrative is about (Newcomb 1994). Those structural oddities may be a function of Chopin's uncertainty about the genre he was employing when composing this work (Kallberg 1985). I will refrain from theorizing the idea of musical narrative, since I have little to add to the growing debate around this topic. Readers who wish to familiarize themselves with these issues may consult several recent summaries (see Monahan 2015, p. 63-74; Klein 2013; Almén 2008, p. 11-37). For the purposes of the present analysis, musical narrative is the study of the dramatic/affective logic of a work and at least one culture idea embedded in that logic. No narrative analysis can pretend to be exhaustive in either of these areas. As with narratives themselves, which must leave out information to make closure a possibility, this one will concentrate on only a few passages from the Polonaise-Fantaisie.

\section{2 - The Beginning}

The final measures of the Polonaise-Fantaisie are a pared down version of the opening, although there is a reversal in the dynamic intercutting. The piece opens with a pair of stentorian chords, moving from $\mathrm{Ab}$ minor, to the flat mediant, $\mathrm{Cb}$ major, with a change of dynamics from loud to soft over the second chord, while the move into the upper register unfolds slowly through an arpeggio embellished with cambiatas (Example 3).

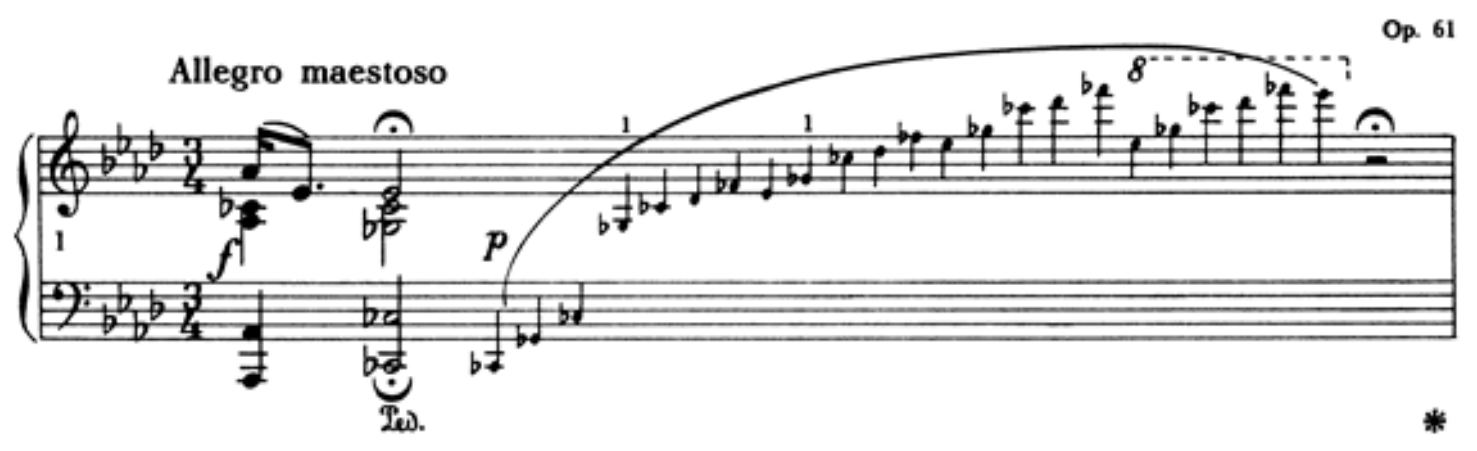

Example 3: Opening of Chopin's Polonaise-Fantaisie

Here Gérard Genette's concept of the paratext (titles, illustrations, epigraphs that help us interpret the main text) guides us to a first understanding 
of the opening gesture (Genette 1997). In Chopin's time, the fantasy had accrued a set of associations, including notions of imagination, caprice, or a willingness to move freely from one musical idea to another. A fantasy could be a potpourri of themes, but it could also point to an expansion of form, a rise in the exploration of the artist's interiority (Kallberg 1985, p.268-75). We can read the quiet arpeggio, then, as an expression of the fantasy aspirations of this piece. As for the muscular opening chords, we might take them as a metonym for a polonaise, a dance that in the France of Chopin's time was indexical to the lost splendor of Poland and the promise of a national independence yet to come (Liszt 2005, p.12-14).

The opening thus brings together the two-part title of the work, where the heroic chords signify the polonaise, and the sudden drop in dynamics and ethereal floating into the piano's stratosphere signify the quicksilver change indexical to a fantasy. The work is somehow not a polonaise, and not a fantasy, but both at the same time. The sudden affective swerve in the first measure is like the hyphen in the title. It is not that this is a polonaise in the form of a fantasy, or a fantasy with some polonaise rhythms. Instead, the two genres stand in opposition to each other while flowing from each other at the same time. I interpret that opposition (Polonaise/Fantasy) as akin to doing and dreaming. In historical terms, the doing/dreaming opposition was playing itself out in Chopin's time as the Polish diaspora's political move to nudge France into sending military aid to Poland and fulfill the dream of freedom (Goldberg 2004). Doing and Dreaming.

But there is more. The two harmonies of the first measure play themselves out as the most important tonal centers of the Polonaise-Fantaisie. Much of the first half of the piece unfolds a polonaise in $\mathrm{Ab}$, while at the midway point, the music moves to a mixed topic (a nocturne and a preghiera) in B major, the enharmonic twin to $\mathrm{Cb}$ (Example 4). Doing and dreaming, polonaise and nocturne, $\mathrm{Ab}$ and $\mathrm{B}$ are all pre-figured in that astonishing opening measure. This assemblage of ideas gives us an inkling of what the last three chords of the Polonaise-Fantaisie might signify: the awaking from a dream.

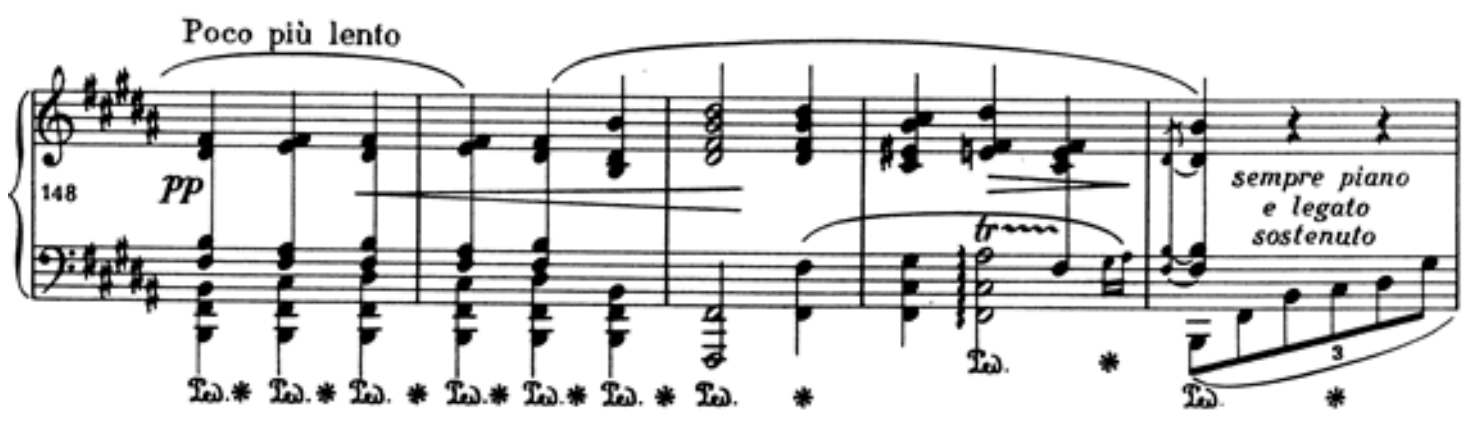

Example 4: Middle Section of Chopin's Polonaise-Fantaisie 


\section{3 - Träumerei}

It takes a long time for the polonaise proper to make an appearance. First, the opening gesture unfolds a long introduction that promises little in the way of narrative action. The first measure plays a part in a sentence structure, whose repeated basic idea moves down by step for a second pair of chords, Gb and the impossible B double-flat: the music falls into a dream once again. The continuation phrase reaches lower to $\mathrm{Fb}$ in the bass before landing on the dominant, $\mathrm{Eb}$, completing a conventional linear descent from tonic to dominant.

From this point, Chopin might easily have introduced the polonaise directly. Instead, the entire sentence structure appears a second time (Example 5), beginning on the minor dominant and including a varied and much longer continuation segment.
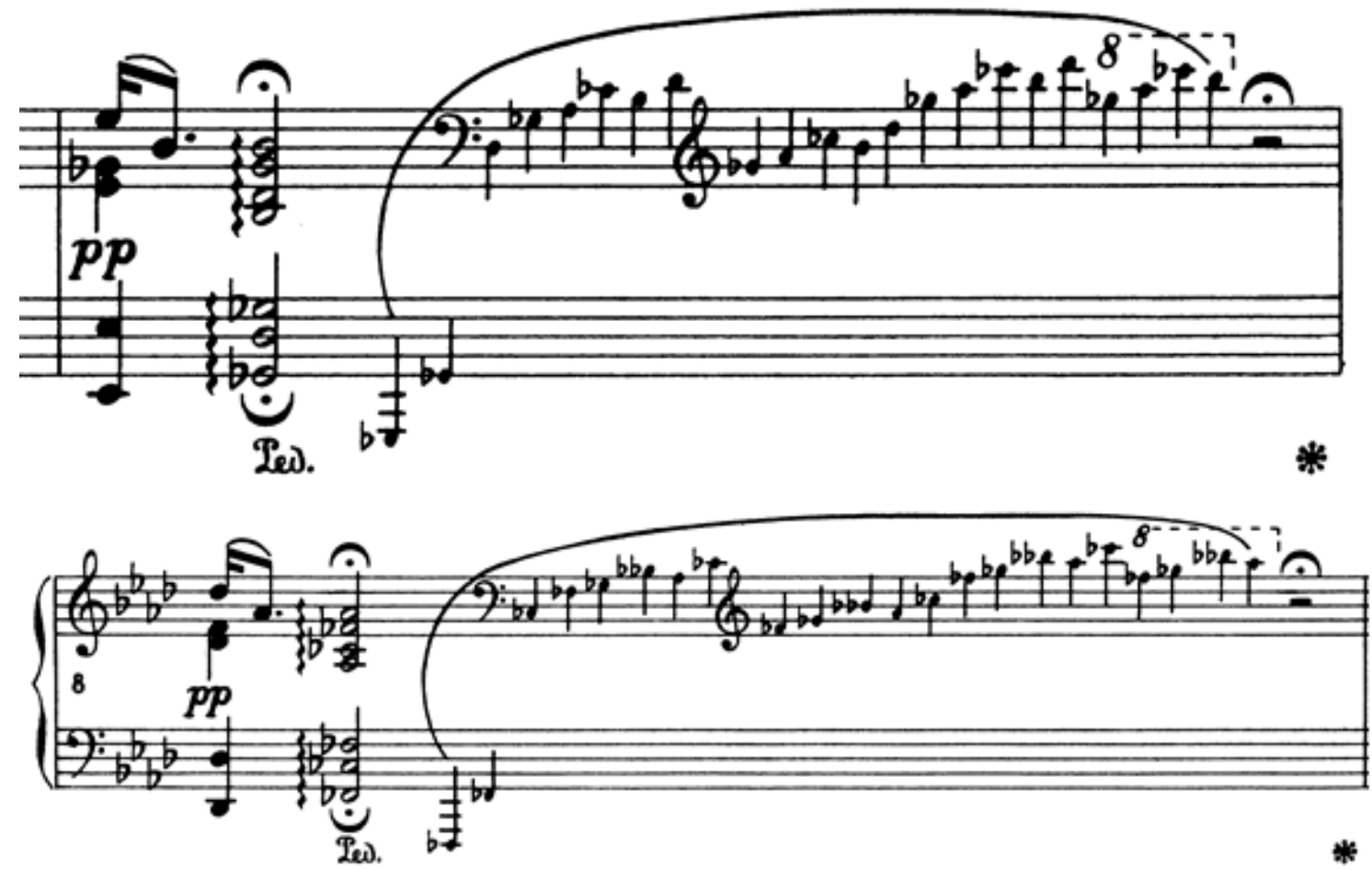

Example 5: Repetition of Introductory Material in Polonaise-Fantaisie

Now the chordal pairs are hushed, as if the polonaise to which they point is only a reverie of military action: Träumerei (Example 6). This time, the continuation segment hints at the polonaise to come but gets stuck on a B pedal before finding a cadence in G\# minor at measure 19. So close to the home key:

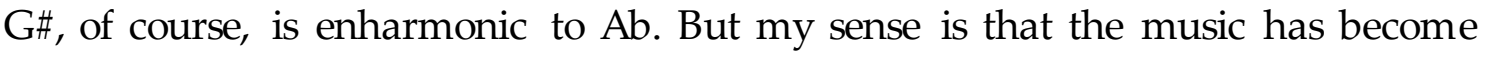
lost, that G\# minor is a shadow key, a doppelgänger forecasting an inconvenient truth: that the heroic musical personal who entered so full of energy in the first 
measure has gone astray before the first real action can take place. The situation becomes dire when the introduction halts on a questioning half-cadence preceded by a Neapolitan (m. 21-22).

The music must cross the boundary from this unheimlich turn to the promise of light and action. The prototypical polonaise rhythm simply startles the musical persona awake with octave Eb's in measure 22 (Example 6). At last, the polonaise can begin. The entire introduction is like falling into a dream, from which the polonaise rhythm awakens the musical persona. The idea of waking up that I read into the final chords of the work is prefigured in an extended form in the introduction.

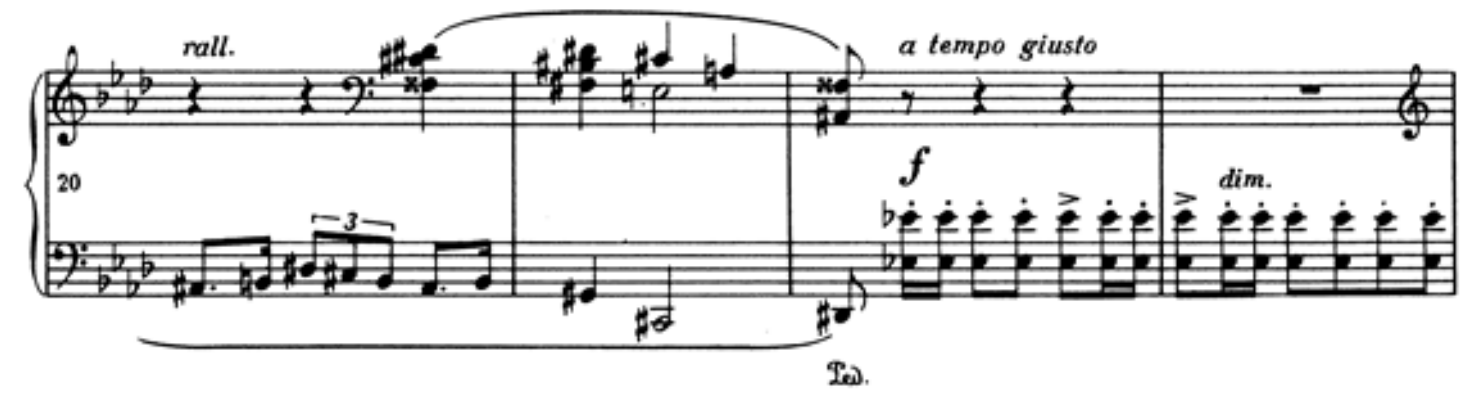

Example 6: Conclusion of Introductory Material

\section{4 - Everything That Happens Twice...}

I'm afraid we're not finished with the introduction. In Paulo Coelho's novel The Alchemist, we learn an Arab proverb: "Everything that happens once can never happen again. But everything that happens twice will surely happen a third time" (Coelho 1998, p. 156). The introduction to the Polonaise-Fantaisie moves through its opening sentences twice, so we should expect that they will happen a third time. The music does not disappoint. Like Santiago, the main character in The Alchemist, who is robbed twice in the beginning of his story and a third time near the end, the introduction returns much later in the work for its third appearance shortly before the concluding apotheosis. Just prior to this return was a long nocturne section, acting as a dream sequence. The music accomplishes an authentic cadence in B major (m. 206), and the left hand unravels over that local tonic to make a gentle landing on a B-major chord in $\mathrm{m}$. 214, initiating that return of the introductory material (Example 7). 

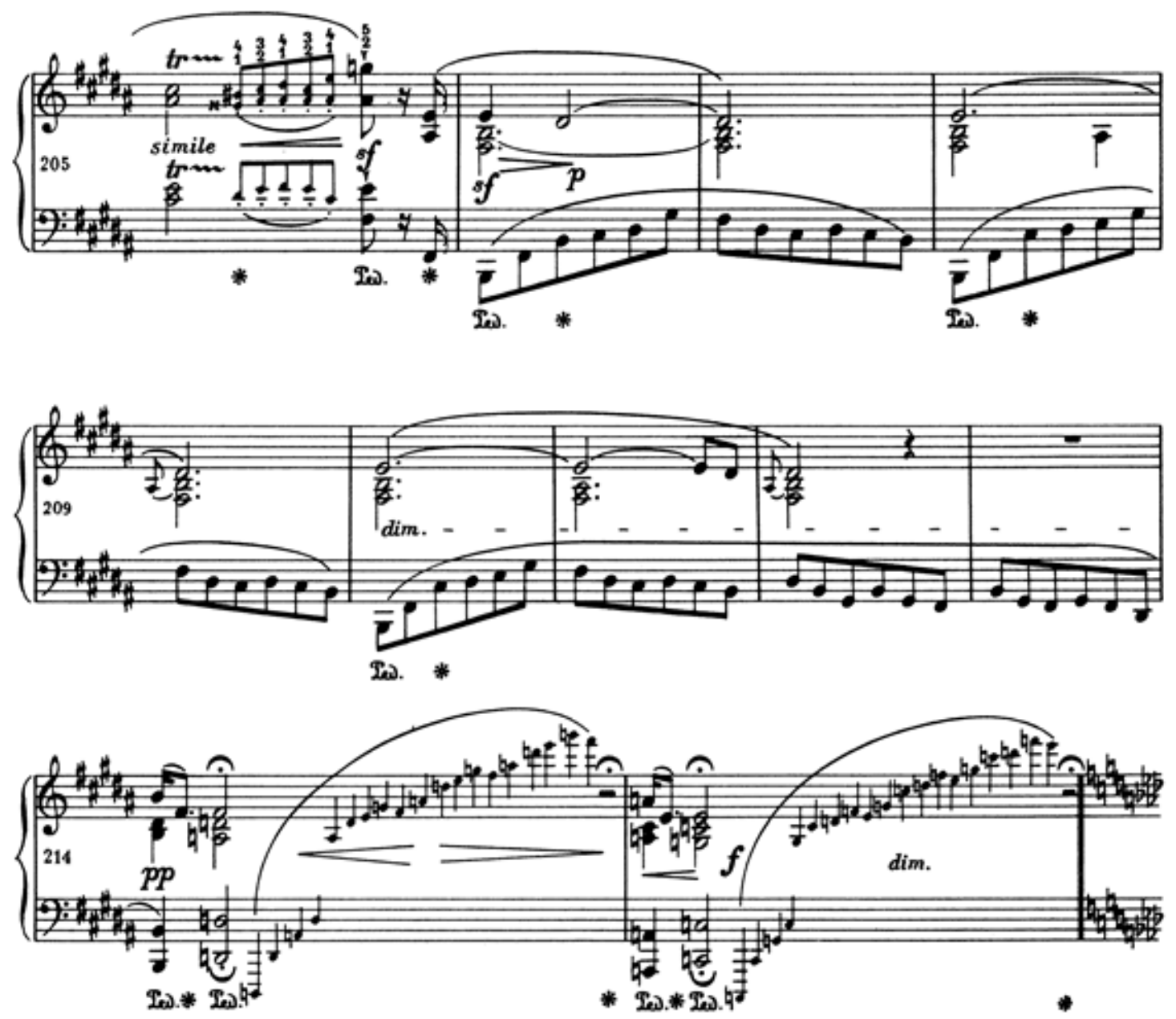

Example 7: Return of Introductory Material after Dream Sequence

Here we fall into a dream within a dream. Instead of the declamatory two chords that marked the beginning of the work, the music whispers the new tonic, B major, and its chromatic mediant, D, which follows its pre-ordained course through ascending arpeggios. As expected, this basic idea is repeated in sequence a step lower to reveal the unlikely Neapolitan pair: A (the enharmonic Neapolitan to the home key), and C major, the Neapolitan to the dreamsequence's B major. But there is no sense of the uncanny here. Instead, for the first time in the threefold appearance of these sentence structures, the arpeggio on the C major chord begins firmly and confidently, including the lowest sounding note of the piece. The music has found its stature only to lose it once the arpeggio finds the upper register. C major, the key of reality, is the place from which the music will wend its path to its double apotheosis. The threefold introductory sentences, then, play two parts in the doing/dreaming opposition. At the beginning of the polonaise, the sentences move from the promise of action 
to the idleness of dreaming, while near the end of the polonaise, the sentences move from a dream within a dream back to the promise of action.

\section{5 - A Polonaise}

Before we get to that apotheosis, we will take a brief look at the work's two main themes. First, the polonaise. The polonaise begins with its own sentence structure: a 4-bar phrase in $\mathrm{Ab}$, followed by a sequential repetition in $\mathrm{Bb}$ minor; the theme concludes with a long continuation segment that fills twelve measures before finding a resting point on the dominant. But there is something wrong with this polonaise theme. Although it is introduced with the heroic polonaise rhythm in the left hand, the theme itself lacks the dotted rhythms and the élan that Liszt described as "galvaniz[ing] and "electrify[ing] the torpor of indifference" (Liszt 2005, p. 12). Liszt's choice of words could not be more apt, since Chopin's polonaises were meant to galvanize the torpor of French indifference toward the Great Emigration of Poles due to the Russian occupation of Poland. But this polonaise has more of a singing style, like the humming of a half-remembered tune with its simple neighbor motion. The conventional sixteenth-note accompaniment lacks the usual octave or chordal support of Chopin's other polonaises, as if it comes from a distance. It isn't until the continuation segment that the music finds its heroic voice. And when the trumpets blare their warnings in a tonicized F minor, the theme still manages to push away the military connotations in the lead up to the half cadence (Example 8). 

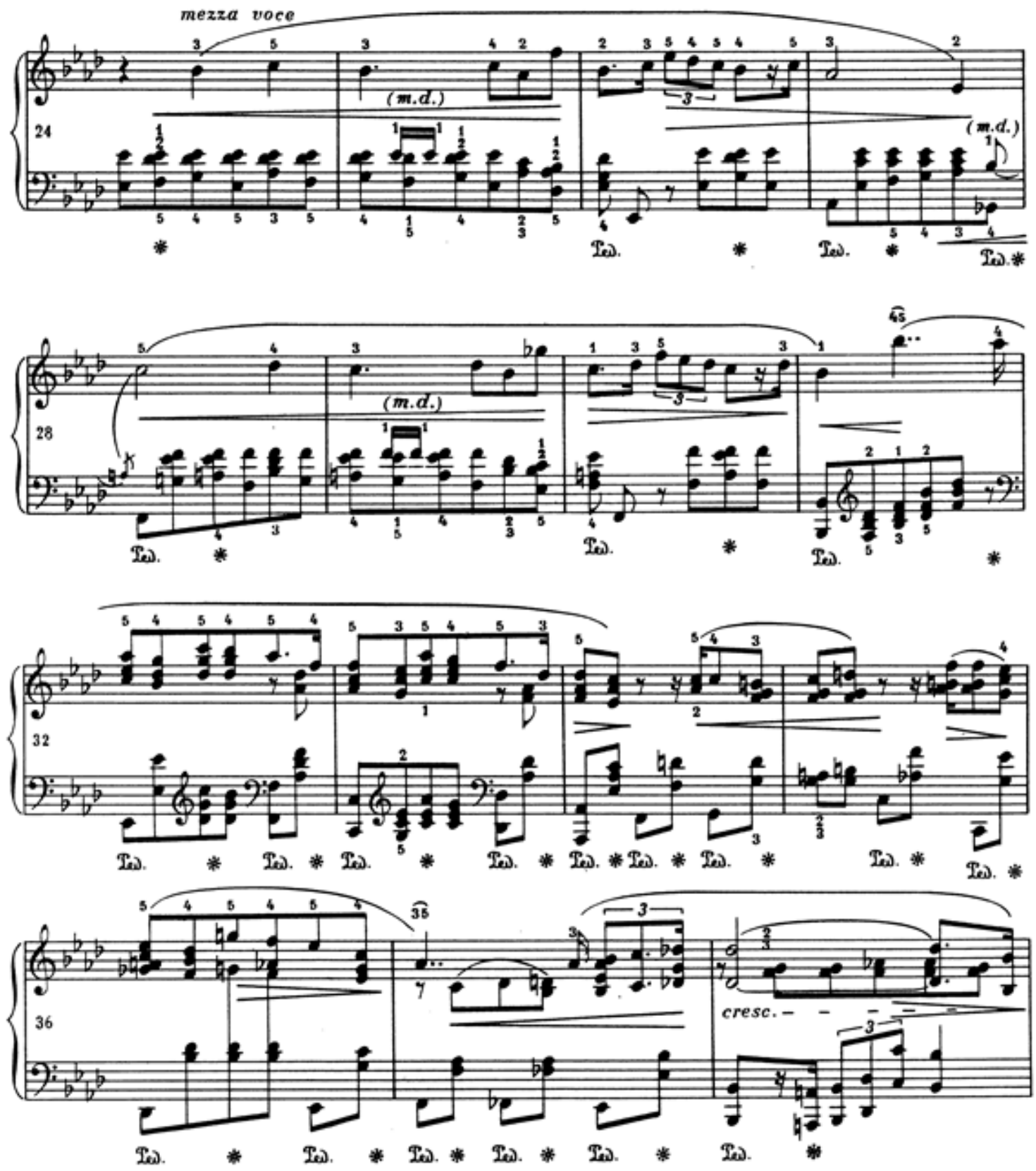

Example 8: Polonaise Theme

The polonaise theme forms itself again, creating a grand antecedent/consequent structure. This second time, the theme's continuation phrase is in two parts: a virtuosic section to gather momentum, and a tragicheroic section in the true polonaise style. The music at last sustains narrative action. Even here, though, the perfect authentic cadence that closes the main theme returns to a softer dynamic, while a chorale texture and modal mixture lend the music a sense of nostalgia, as if the whole scene were from an irretrievable past. This is a theme that wants desperately to be a polonaise but 
can only sing of one. The interpretative question is whether the polonaise truly presents narrative action, or whether it can only dream of narrative action. The doing/dreaming opposition, like all oppositions, has trouble maintaining itself. From this standpoint, the Polonaise-Fantaisie is like a deconstruction of doing/dreaming, indicating that each is defined in terms of the other, and each has the other in the definition of its term. We act on dreams, and we dream of action.

\section{6 - A Prayer}

By the middle of the Polonaise-Fantaisie, the dream world forestalls the possibility of directed action. The music comes to a chorale topic, indexical to signs of spirituality and transcendence, followed by a section that mixes features of the nocturne, and of the preghiera, a type of nineteenth-century aria in which the singer prays for salvation. As with the polonaise, though, these topics are marked by strangeness. The chorale, for example, is brief and splits its melody between a rising figure in the tenor, and a repeated note in the upper voice (Example 4). In addition, the phrase ends with a trill in the tenor, an embellishment completely out of character for this topic. The repeated note (an intonation, a meditation) and the trill (a shimmer) send the topic out of the usual communal implications of a chorale and into a private register, as if we hear a secret thought tinged with an inner glow. This music has reached its deepest interiority.

Strangeness also marks the nocturne/preghiera topics that follow. Again the upper voice is minimal in contour, simply alternating between two notes, perhaps indicating that the meditative aspect of the chorale continues (Example 9). The bass melody is far more active and striking for its wide contour. The section exhibits the signs of a nocturne, indexical to erotic intimacy. But the erotic implications are at odds with the sacred intimation of the preghiera. Perhaps the section expresses the sacredness of intimacy, or the intimacy of the sacred. At the same time, the entire section reveals an inner life that was becoming the focus of nineteenth-century music and literature. This inner life, which connects admirably to the cultural codes around the genre of the fantasy, is at odds with the public and military implications of the polonaise. 

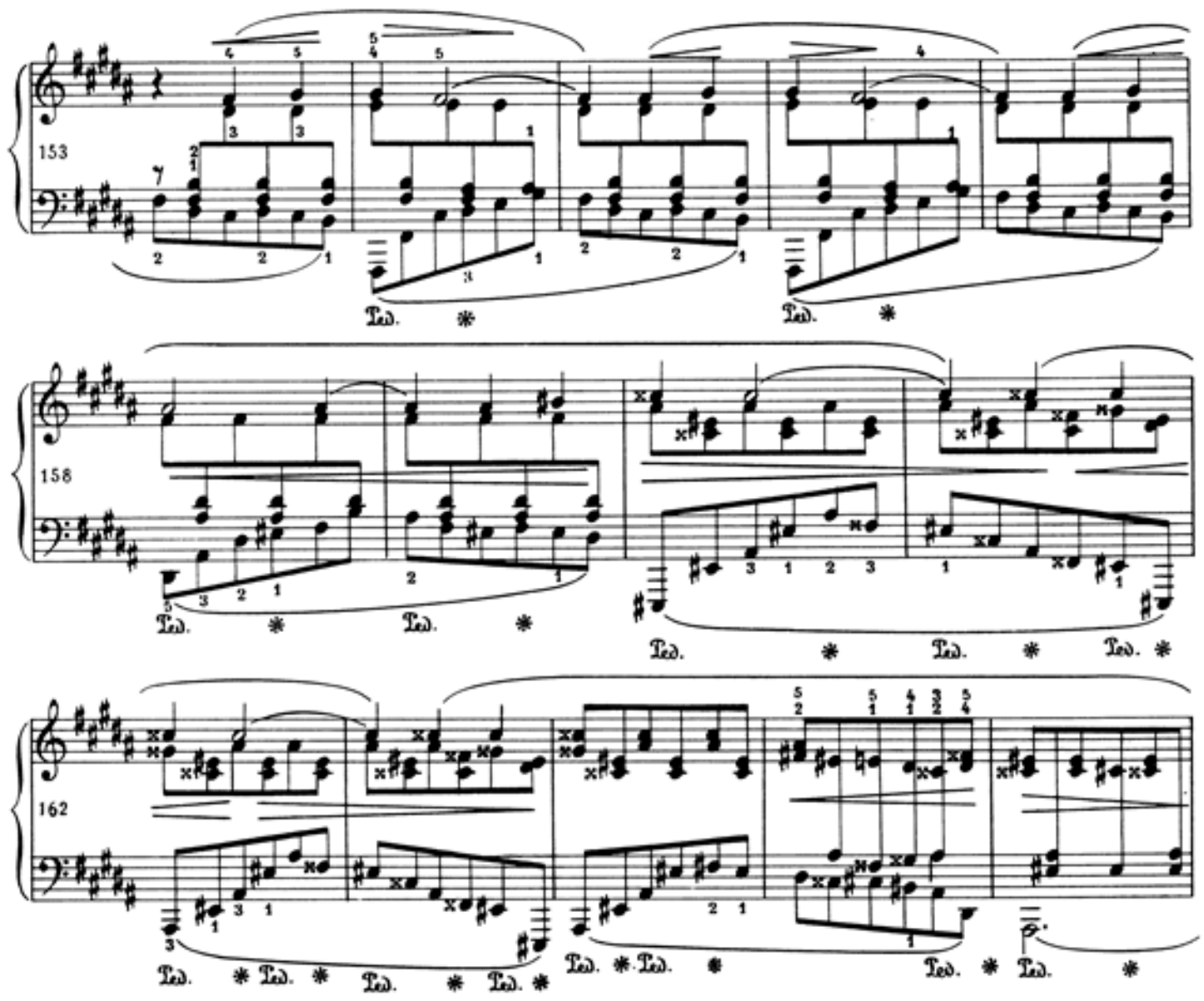

Example 9: Nocturne Theme

The nocturne unfolds over the most unassuming harmonic support, toggling between the dominant and the tonic. The upper-neighbor motive that opens this theme is shared by the polonaise theme, as if we witness not a new character but another side of a single character. Just when we think the theme is trapped harmonically, it moves to the most unlikely of keys: A\# major, the key of this section's leading tone, achieved through a sudden $6 / 4$ chord that signifies a magical glimpse of some distant Polish idyll (m. 160). This thematic agent may have little potential for action, but it does have a secret knowledge, revealed through its ability to enter the most distant of keys, which is more visionary than the harmony of the polonaise. Still, during a replaying of this theme, the agent wends through a harmonic path that leaves it stranded on an augmented- $6^{\text {th }}$ chord, suggesting a modulation to $\mathrm{E}$ minor - a modulation that never materializes (Example 10). The music simply stops, and when it picks up the harmonic thread, a single voice (the voice of the narrator) carries the music to G\#minor and a mazurka (m. 182). The harmonic non sequitur is the signifier for a 
narrator who decides to restart the story in a new place after having lost the narrative thread.
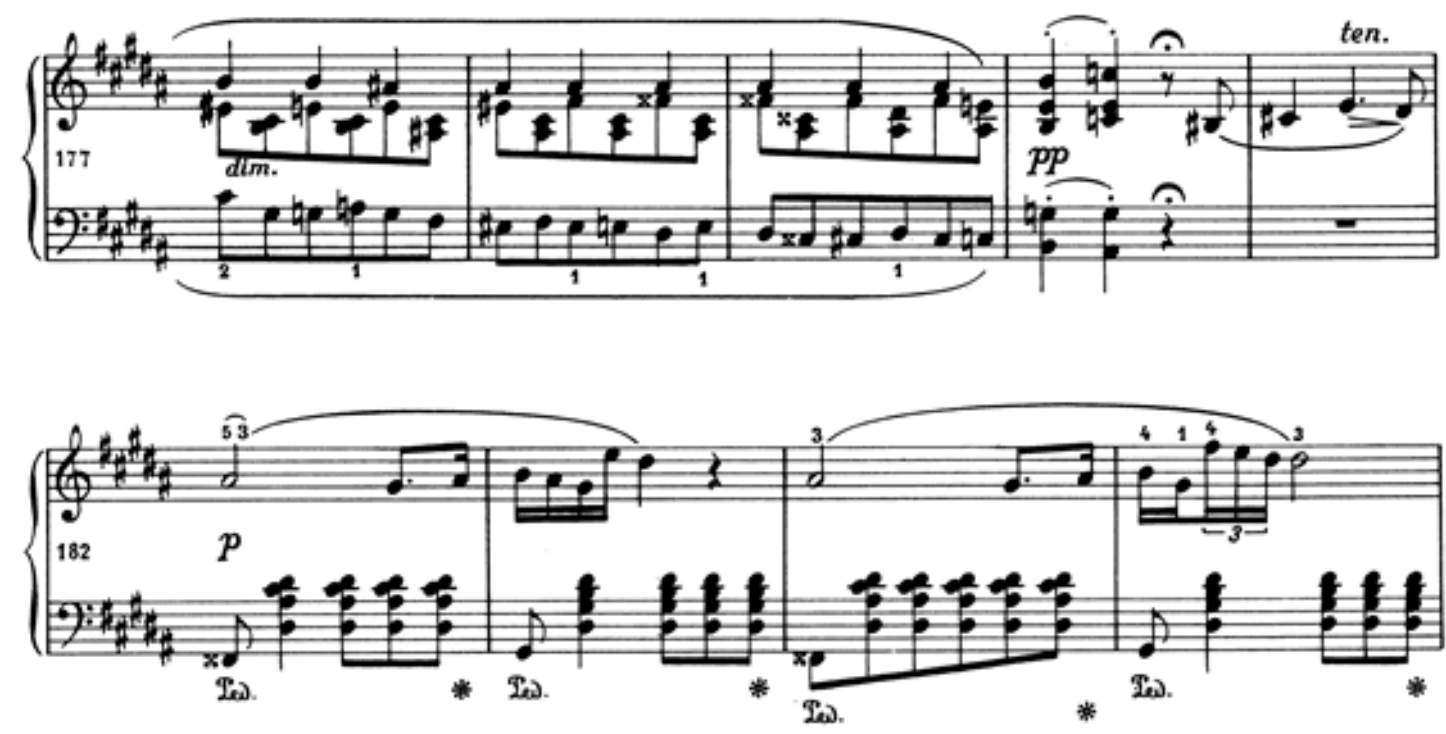

Example 10: Conclusion of Nocturne Theme

\section{7 - An Apotheosis}

The Polonaise-Fantaisie plays out the doing/dreaming opposition in the course of its apotheosis. In the semiotics of narrative, as theorized by Byron Almén, a member of a culture chooses which side of an opposition is more valued and then tracks the success or failure of that side throughout the story (Almén 2008, p. 47-54). In this case, I surmise that members of Western culture value doing over being, action over dreaming. Semioticians would call this a "valuation" of an opposition, which is reinforced in our culture through countless narratives of heroic action. Expressed simply, within Western culture, doing is valued over being (or dreaming). A narrative in which the hero does nothing would be a marked one because it asks us to accept non-action as a viable heroic alternative. Proust's In Search of Lost Time, focused as it is on memories, and lacking narrative action as it does, is just such a marked narrative, asking the reader to reconsider (transvalue) the doing/dreaming opposition in favor of dreaming as a viable heroic choice.

In short, the Polonaise-Fantaisie concludes with an apotheosis, which, in nineteenth century music, marks a theme as an unqualified success. And because it begins its apotheosis with the polonaise theme, the narrative marks doing as the worthy cultural value. The apotheosis begins with the polonaise theme over the putative structural dominant of the piece, but just as the success of the 
polonaise is assured, a harmonic breakthrough sends the music to B major, the key of the nocturne, over a 6/4 chord. This amped-up passage sends the polonaise into the harmonic realm of the music's dream. A quality of the dream in the nocturnal music has taken on the characteristics of action, co-opting both the polonaise and its key.

Moving through another chromatic passage, the music returns to the structural dominant as the nocturne theme unfolds in its own apotheosis. And it is this theme (the nocturne) that manages to reach a Perfect Authentic Cadence in the home key: the ultimate sign of success in a tonal narrative (see Hepokoski and Darcy 2006, p. 16-20). But I do not read this victory of the nocturne and its associated values as a remarking of the original opposition, replacing the cultural value of doing with one of dreaming. Instead, I read the music as having undergone a synthesis in which doing and dreaming come together to tell us the secret of our place in the world: our task is to dream and to act. As Proust reminds us: "If a little day-dreaming is dangerous, the cure for it is not to dream less but to dream more, to dream all the time" (Proust 2003, p. 577).

From the standpoint of the Polonaise-Fantaisie as working out the problem of doing and dreaming, the final chord, as has been evident all along, is a waking up, a return to reality after the piece has fallen into dream once more. But why does the music fall into this dream after the success of the nocturne? Our first interpretation has turned out to be, as Žižek tells us about interpreting, too easy (Žižek 1989, p. 4). We are prompted to reach for a second interpretation, which will come via a reconsideration of intertextuality and subjectivity.

\section{8 - Intertextuality Revisited}

Implicit in the analysis so far has been a conception of intertextuality. Kofi Agawu recognized that topics depend on intertextuality, while I have argued elsewhere that intertextuality also points to the strangeness in the use of a topic, which in turn opens interpretation (Agawu 1991, p. 35; Klein 2005, p. 95-98). In the Polonaise-Fantaisie, we recognize the strangeness of the polonaise, the chorale, and the nocturne through its intertextual web with other tokens of those topics. These connections prompt the interpretation that the polonaise at first lacks the heroic emphases of other polonaises, and that the nocturne with its implications of dreaming is not a likely candidate for the closing apotheosis.

But intertextuality as a crossing of texts was not the focus of Julia Kristeva's seminal essay, "The Bounded Text," which first coined the term intertextualité (Kristeva 1980, p. 36). Kristeva was re-imagining Mikhail Bakhtin's work on the novel, which involved a mix of different kinds of writing, or what Kristeva called "a typology of texts" (Kristeva 1980, p. 36; emphasis in original). 
The typology of the novel included what Kristeva called "citation", which had a broad range of meanings (Kristeva 1980, p. 45-47). A citation could be dialogue, or an actual quotation, but it could also be a temporal marker, a commonplace, a common phrase or idea, etc. Intertextuality in Kristeva's conception, then, is a general term for any segment marking a difference in the typology of a text. Turning to music, it is not the single topic in a piece that marks intertexuality but a mix of topics within a single piece that forms a typology that is intertextual. The Polonaise-Fantaisie is not an intertextuality because the polonaise theme points to other polonaises but because the piece itself is a riot of topics: in addition to the polonaise and nocturne, the piece exhibits a fantasy topic, a mazurka, ombra, cantabile, coloratura, recitative, virtuosic style, and on and on.

The jostling of topics brings us to the ideology of the closed text. Kristeva argued that intertextuality made the smooth surface of the novel an illusion, an ideology. As a consequence of the various discourses rupturing the surface of the novel, the author would bind the text into an apparent unity that necessitated a "reevaluation of the bourgeois social text" (Kristeva 1980, p. 58). Any ideology that maintains the literariness of a text by virtue of its closed and unified quality is simply an excuse for upholding a bourgeois view of the world. Further, a quest to demonstrate such a unity is blind to the productivity of intertextuality, which performs a redistribution and renewal of language.

Chopin often does very little to hide the disruptions of the topical shifts in the Polonaise-Fantaisie. During a stormy version of the polonaise theme (m. 108), for example, the music turns without preparation to a cantabile topic at $\mathrm{m} .116$ (Example 11). From Agawu we know that it is the tonal processes at deep levels of structure that bind together the various topics of a piece (Agawu 1991, p. 17$25)$. In this case, the music takes $\mathrm{Bb}$, the local tonic of the second basic idea, as a launching point for the continuation phrase, which marks the new and unusually contrastive cantabile topic. From a viewpoint informed by Kristeva, tonal processes such as this one, which bind together contrastive material, are an ideology that hopes to make the typology of a text into a unity. Because tonality is an ideology, it functions to hide as much as it exposes. What it hides in this case is what Kristeva called the "bourgeois social text." That is: tonal structures present an ideology of unity (matching the supposed unity of the bourgeois social world) where there is surface disruption. The narrative of the Polonaise-Fantaisie, which began as a way of trying to understand the unfolding of an opposition, brings us at last to a greater point involving subjectivity. 

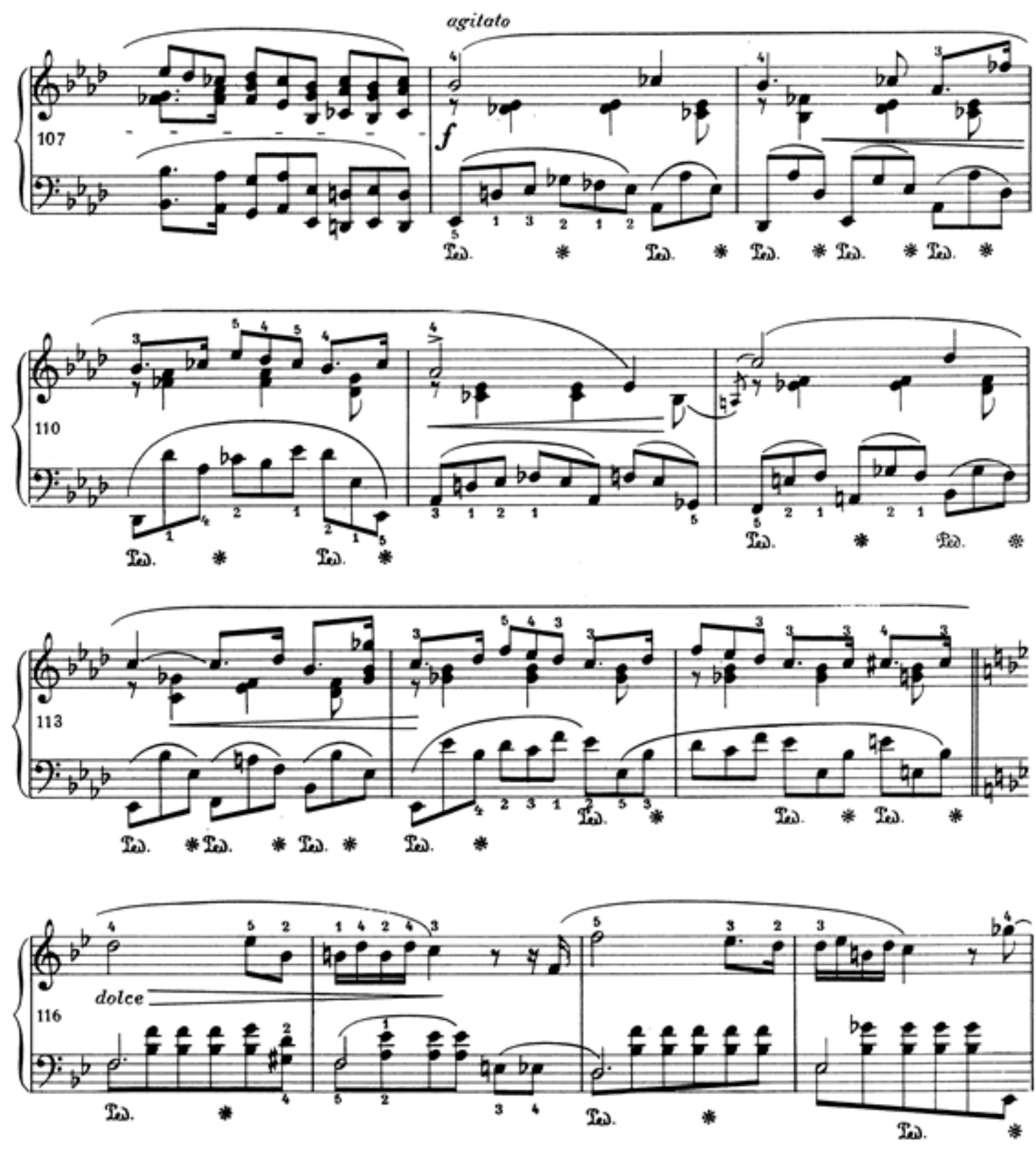

Example 11: Sudden Change of Topic in Polonaise Variation

\section{9 - Subjectivity Revisited}

With the phrase "bourgeois social text," Kristeva was pointing to a model of subjectivity that prized unity in order to uphold the capitalist idea that a person accomplishes the accumulation of wealth through a fully independent agency. There is no clearer portrait of this ideology than in the character of Josiah Bounderby from Dickens's Hard Times, written less than a decade after Chopin's Polonaise-Fantaisie. In the novel, Mr. Bounderby, who boasts of being a self-made man, is exposed as a fraud when the townspeople discover that his parents set 
him on his path with a large sum of money, rather like Donald Trump. But it is this old model of subjectivity that is fraudulent. We are not singular; we are plural. As Lacan might put it, we have been duped by a trick of grammar: the I with which I speak hides the we of the fragmented (intertextual) inner world.

The inner world is a master signifier here. In the $18^{\text {th }}$-century model, the inner world, the Kantian phenomenological, is separated by an imaginary fixed boundary from the outer world, the noumenal. Each of us is a monad, in the words of Rousseau, "not made like any of those who are in existence" (Rousseau 1904, 1). But the Freudian and Lacanian revolution is one that recognizes that the most private of worlds, the unconscious, is not singular, it is plural. When Freud speaks of the unconscious, he speaks of a culture, a fact made plain by Lacan's term "the symbolic order," a cultural configuration into which we are born. Thus the famous Lacanian aphorism: the unconscious is the Other's discourse (Lacan 2006, p. 10; emphasis in original). Or, in plainer terms, my private world has been formed in advance by my culture.

Chopin's Polonaise-Fantaisie stages the problem of interiority at the historical moment when interiority becomes prized as a world of greater standing than the outer, objective one. The polonaise, a public expression of Polish pride, is interrupted by the signs of the inner world in the topics of fantasy, nocturne, and cantabile. Moments when the music awakens are followed by a discourse that refuses the logical sequence of topical events that we might expect in the outer world. And an apotheosis that should scatter the problems of subjective thought only leads to another sign of an inner world in the trills and winding down of the final phrase. Despite this staging of an inner world in keeping with Chopin's time, the inner and outer worlds are not as separate as the bourgeois social text would like us to believe. From this point of view, that final chord in the upper register is not so much a waking up in the literal sense as a waking up in the metaphorical sense; it is a realization of the multiplicity that constitutes us. This narrative reading exceeds the mandate of authorial intent, as many interpretations do. But it also gives to the study of musical narrative a purpose beyond a simple tracing of a musical logic in dramatic terms; it gives to the study of music a place in how we understand the culture that made us and that always remakes us. 


\section{References}

1. Agawu, Kofi. 1991. Playing with Signs: A Semiotic Interpretation of Classic Music. Princeton: Princeton University Press.

2. Almén, Byron. 2008. A Theory of Musical Narrative. Bloomington: Indiana University Press.

3. Coelho, Paulo. 1998. The Alchemist, trans. Alan R. Clarke. New York: HarperCollins.

4. Genette, Gérard. 1997. Paratexts: Thresholds of Interpretation, trans. Jane E. Lewin. Cambridge: Cambridge University Press.

5. Goldberg, Halina. 2004. 'Remembering that Tale of Grief': The Prophetic Voice in Chopin's Music. The Age of Chopin: Interdisciplinary Inquiries, ed. Halina Goldberg. Bloomington: Indiana University Press, p. 54-94.

6. Hepokoski, James, and Warren Darcy. 2006. Elements of Sonata Theory: Norms, Types, and Deformations in the Late-Eighteenth-Century Sonata. Oxford: Oxford University Press.

7. Kallberg, Jeffrey. 1985. Chopin's Last Style. Journal of the American Musicological Society 38/2, p. 264-315.

8. Klein, Michael L. 2005. Intertextuality in Western Art Music. Bloomington: Indiana University Press.

9. 2013. Musical Story. Music and Narrative since 1900, ed. Michael L. Klein and Nicholas Reyland. Bloomington: University of Indiana Press, p. 3-28.

10. Kristeva, Julia. 1980. The Bounded Text (1969). Desire in Language: A Semiotic Approach to Literature and Art, edited by Leon S. Roudiez, translated by Thomas Gora, Alice Jardine, and Leon S. Roudiez. New York: Columbia University Press, p. 36-63.

11. Lacan, Jacques. 2006. Seminar on "The Purloined Letter." Écrits, trans. Bruce Fink. New York: W. W. Norton \& Company, p. 6-48.

12. Liszt, Franz. 2005. The Life of Chopin, trans. Martha Walker Cook. Mineola, New York: Dover Publications. 
13. Monahan, Seth. 2015. Mahler's Symphonic Sonatas. Oxford: Oxford University Press.

14. Newcomb, Anthony. 1994. The Polonaise-Fantasy and issues of musical narrative. Chopin Studies 2, ed. John Rink and Jim Samson. Cambridge: Cambridge University Press, p. 84-101.

15. Proust, Marcel. 2003. In Search of Lost Time, Volume II: Within a Budding Grove, trans. C. K. Scott Moncrieff, and Terence Kilmartin, revised by D. J. Enright. New York: The Modern Library.

16. Rousseau, Jean Jacques. 1904. The Confessions of Jean Jacques Rousseau, Volume I, trans. unlisted. Edinburg: Oliver and Boyd.

17. Žižek, Slavoj. 1989. The Sublime Object of Ideology. London: Verso. 